bare minimum, making them useless to their patients and other doctors alike, or even keep a second set of records under the consulting room table.

Ethical arguments, however, support greater access. Koenigsberger regards the basic question as being not whether access can be harmful but whether patients have a right to know everything about their state of health.$^{11}$ Hochuli has argued that most medical interventions carry a risk of adverse effects to a few patients and that this risk is not a valid argument against greater access. ${ }^{12}$

Should doctors just acquiesce to the new legislation and leave it at that? If they do so they are missing an important opportunity to improve communication between doctors and patients and much else besides. If the potential benefits of greater access are as extensive as the research suggests then a low rate of requests for access should be a cause for concern rather than relief.

To facilitate access new ways of writing records for patients will need to be evolved. New ways of keeping records have been studied and their effects on patients found to be positive. Summary records held by patients have proved successful in obstetrics, ${ }^{13}$ diabetic care,${ }^{14}$ and general medicine. ${ }^{15}$ In psychiatry, where particular concern has been expressed about the potential damage to patients, such records have been used successfully, including among the homeless mentally ill. ${ }^{16}$

The argument against giving patients greater access to their records has been lost; the challenge now is to get doctors skilled in writing records that their patients (as well as their medical colleagues) will find useful. The benefits of such an approach should outweigh the effort required. The change in legislation giving patients greater rights of access should therefore be viewed as a window of opportunity rather than intrusive meddling.

Research Psychiatrist,

PAUL MCLAREN

United Medical and Dental School,

Guy's Hospital,

London SE1 9RT

1 Warden J. Patients to see medical records. BMF 1991;303:538

2 Kirby BJ. Patient access to medical records. $\mathcal{F} R$ Coll Physicians Lond 1991;25:240-2.

Gillhooly MLM, McGhee SM. Medical records: practicalities and principles of patient possession. 7. Med Ethics 1991;17:138-43.

4 Shenkin BN, Warner DC. Giving the patient his medical record: a proposal to improve the system. N Engl f Med 1973:289:688-90.

Andersen $T$, Jorgensen G. Danish experiences of statutory right of patients to access hospital records. Lancet $1988 ;$ ii: 1428

6 Baldry M, Cheal C, Fisher B, Gillett M, Huet V. Giving patients their own records in general practice: experience of patients and staff. BMF 1986:292:596-7.

7 Bernadt $M$, Gunning L, Quenstedt $M$. Patients' access to their own psychiatric records. BMF 1991;303:967.

8 Parrot J, Strathdee G, Brown P. Patient access to psychiatric records: the patient's view. $\mathcal{F} R$ So Med 1988;81:520-2.

9 Stoller RJ. Patients' responses to their own case reports. F Am Psychoanal Assoc 1988;36:371-91. 10 Short D. Some consequences of granting patients access to consultants' records. Lancet $1986 ; 1: 1316$

11 Koenigsberger CW. Access to medical records. Lancet 1986;i:1445.

12 Hochuli VK. Access to medical records. Lancet 1986; i: 1445.

13 Lovell A, Zander LL, James CE, Foot S, Swan AV, Reynolds A. The St Thomas' Hospital maternity case notes study: a randomised controlled trial to assess the effects of giving expectant mothers their own maternity case notes. Paediatr Perinat Epidemiol 1987;1:57-66.

14 Jones RB, Hedley AJ, Allison SP, Tattersall RB. Censoring of patient-held records by doctors. Journal of the Royal College of General Practitioners 1988;38:117-8.

15 Ellis DA, Hopkins JM, Leitch AG, Crofton J. "Doctors' orders:" controlled trial of supplementary written information for patients. BM7 1979:i:456.

16 Reuler JB, Balazs JR. Portable medical record for the homeless mentally ill. BMF 1991;303:446

\title{
Ion channels: this year's Nobel prize in physiology or medicine
}

\author{
Opening channels of communication
}

A revolution on the scale wrought by Erwin Neher and Bert Sakmann is rare indeed so it is entirely appropriate that they should have received this year's Nobel prize in physiology or medicine for their work on cellular communications that involve electrical signals. Their basic idea is simple.

The lipid cell membrane is impermeable to ions, so ionic currents are carried through the membrane by specialised protein molecules - ion channels - that span the membrane. On sensing an appropriate electrical or chemical stimulus ion channels change shape, producing a pore in the membrane through which ions can flow. Such ion channels are important not only in excitable tissues (for example, for the propagation of nervous impulses and for synaptic transmission) but also for just about every other cell type too-from secretory cells to lymphocytes.

The idea that such ion channels must exist evolved during the 1950s, mainly from the work of Alan Hodgkin and Andrew Huxley in Cambridge on the nerve impulse and that of Bernard Katz at University College London on synaptic transmission from motor nerve to muscle. By the early 1970 s there was enough indirect evidence about the channels to guess that a current of a few picoamps must flow through each channel. The noisiness of the recording methods, however, was about 100 times too large to allow such tiny currents to be observed directly. The neuroscientific world was, therefore, stunned when Neher and Sakmann succeeded in observing the currents through single ion channels by means of a new method, the patch clamp technique. ${ }^{1}$

This method allows one to watch, as it is happening, the activity of an individual molecule, something that most chemists and physicists cannot do. The method entails touching a micropipette (tip diameter about $1 \mu \mathrm{m}$ ) against the external surface of the cell membrane in such a way that a high resistance seal is formed between the glass and the membrane, thus isolating a very small area of membrane. When an ion channel opens in this patch of membrane the current flows up the micropipette and can be measured with a sensitive ammeter. ${ }^{2}$

At the Max Planck Institute for Biophysical Chemistry in Göttingen, Erwin Neher (trained as a physicist) and Bert Sakmann (trained in medicine, and now working in Heidelberg) not only developed the method but also pioneered most of its important applications. Initially they used the method to investigate the mechanisms of the nicotinic acetylcholine receptors, ${ }^{3-6}$ work that also involved new theoretical approaches to deal with the random probabilistic behaviour of single molecules. ${ }^{7}$ Neher developed a variant of the method that allowed the fusion of secretory vesicles with the cell membrane in mast cells to be observed directly $^{8}$ and has gone on to make enormous contributions to problems of neurosecretion. ${ }^{9}$ Sakmann has a longstanding interest in the development of synapses ${ }^{10}$ and has done pioneering studies, in collaboration with molecular biologists, on the relation between the protein structure of ion channels and their function. ${ }^{11} 12$ More recently he has started to define the nature of synaptic transmission in the brain with the sort of precision, unimaginable without the patch clamp, that was achieved 20 years ago in the peripheral nervous system. ${ }^{13}$ 
The methods they developed have now spread throughout the world and have revolutionised work in many disciplines. They have been used to investigate new drugs and pathological and normal physiological processes. They have contributed to a leap in our understanding of insulin secretion and hold out the promise of a better understanding of synaptic transmission in the brain - of obvious relevance to diseases such as epilepsy.

Neher and Sakmann are scientists' scientists. They write modestly, without hyperbole or self advertisement, about what they have discovered (in a style reminiscent of that of Bernard Katz). Science and medicine have benefited, and will continue to benefit, enormously from their work. The Nobel committee has done the right thing to recognise its importance.

DAVID COLQUHOUN

Department of Pharmacology,

University College London,

London WC1E 6BT
1 Neher E, Sakmann B. Single channel currents recorded from membrane of denervated frog muscle fibres. Nature 1976;260:799-802.

2 Hamill OP, Marty A, Neher E, Sakmann B, Sigworth FJ. Improved patch clamp techniques for high resolution current recording from cells and cell-free membrane patches. Pflugers Arch 1981;391:85-100.

3 Neher E, Steinbach JH. Local anaesthetics transiently block currents through single acetylcholinereceptor channels. F Physiol 1978;277:153-76.

4 Sakmann B, Patlak J, Neher E. Single acetylcholine-activated channels show burst-kinetics in presence of desensitizing concentrations of agonist. Nature 1980;286:71-3.

5 Fenwick EM, Marty A, Neher E. A patch-clamp study of bovine chromaffin cells and of their sensitivity to acetylcholine. I Physiol 1982;331:577-97.

6 Colquhoun D, Sakmann B. Fast events in single-channel currents activated by acetylcholine and its analogues at the frog muscle end-plate. $f$ Physiol 1985;369:501-7.
and

7 Colquhoun D, Hawkes AG. On the stochastic properties of bursts of single ion channel openings and of clusters of bursts. Philos Trans R Soc Lond [Biol] 1982;300: 1-59.

8 Neher E, Marty A. Discrete changes of cell membrane capacitance observed under conditions of enhanced secretion in bovine adrenal chromaffin cells. Proc Natl Acad Sci USA 1982;79: 6712-6.

9 Penner R, Neher E. The role of calcium in stimulus-secretion coupling in excitable and non excitable cells. $\mathcal{F}$ Exp Biol 1988;139:329-45.

10 Brenner HR, Witzemann V, Sakmann B. Imprinting of acetylcholine receptor messenger RNA accumulation in mammalian neuromuscular synapses. Nature 1990;344:544-7.

11 Imoto K, Busch C, Sakmann B, Mishina M, Konno T, Nakai J, et al. Rings of negatively charged amino acids as determinants of acetylcholine receptor channel conductance. Nature 1988;355. 645-8.

12 Keinanen K, Widsen W, Sommer B, Werner P, Herb A, Verdoorn TA, et al. A family of AMPA selective glutamate receptors. Science 1990;249:556-60.

13 Edwards FA, Konnerth A, Sakmann B. Quantal analysis of inhibitory synaptic transmission in the dentate gyrus of rat hippocampal slices: a patch-clamp study. $\mathcal{F}$ Physiol 1990;430:213-49.

\section{London's health service}

\section{Need to resolve Mr Waldegrave's paradox}

In his speech to the Conservative party conference last week the Secretary of State for Health called it a paradox: there are "more resources for London patients but, in some parts, fewer services than for patients in the provinces."

In a welcome move away from a high risk, market determined solution to the problem of health care in the capital Mr Waldegrave has appointed Professor Sir Bernard Tomlinson, former chairman of Northern region, to act as his special adviser. Sir Bernard's job is to form a strategic view of future needs for health services, medical education, and research in London and then to help broker changes that the health secretary described starkly as "inevitable."

"Which teaching hospitals will close?" and "Will there be one regional health authority for London?" are among the questions that will assail Sir Bernard from every side as his team of experts begins its work.

He will do well to ignore them. While both issues are of consuming interest for everyone concerned in the capital's health care, his approach to the "London problem" will be seriously flawed if it takes institutional and structural issues as its starting point. Instead, the inquiry should concentrate on Mr Waldegrave's paradox: the mismatch between the needs of London's population and the city's existing pattern of health services.

Commissions into London's health services are nothing new: in 1904 the Daily Mail published a map showing the concentration of hospitals in central London and argued that sales of sites should fund a move to the suburbs. In postwar times inquiries into the future of health care in London have taken place about once every 10 years. ${ }^{1}$ In the early 1980 s the Flowers commission and the London Health Planning Consortium worked to reconcile the demands of medical education and research with service needs-with mixed results.

Two factors should mean that Sir Bernard's inquiry is different. The first is the backdrop of the NHS reforms. Purchasers in the home counties and outer London are beginning to make clear their intention to let fewer contracts for costly London services as the "steady state" requirements of the first year of the reforms are lifted. The danger this holds for London's teaching hospitals is very real: "in a market where there is over-capacity of a costly service there is no alternative to radical change." This prospect is made more pressing by the move to funding by weighted capitation, which will diminish resources for health authorities in inner London.

The second factor is widespread recognition that there is an overriding imperative to improve health services for London's population. The facts that waiting lists for London residents are among the longest in the country and that its general practitioners regularly have difficulty in obtaining treatment for acutely ill Londoners have clearly not escaped $\mathrm{Mr}$ Waldegrave. ${ }^{3} \mathrm{He}$ has asked Sir Bernard to concentrate initially on strengthening the city's purchasing authorities to ensure that they can secure the health care that their residents require.

All this means that Sir Bernard-and the capital's health care purchasers and providers - are going to have to think fast about delivering a very different service mix from the traditional, acute hospital dominated London blend. Methods for strengthening and developing the city's patchy primary and community health services will be top of any such agenda. Devising better ways of handling the health and social care needs of elderly Londoners - who are often both poor and socially isolated-will come next. Then there is the challenge of devising health services for people who are disabled by mental health problems, learning disabilities, or chronic ill health - not to mention London's homeless, and other vulnerable groups such as children.

Essentially the job must be to restructure the capital's health services to meet the needs of a mobile, twenty first century inner city population with extremes of both poverty and wealth. Given London's current investment in secondary and tertiary health services, devising such a programme will not be easy. And Sir Bernard's team faces another major challenge: identifying and protecting established excellence in clinical care, medical education, and research as services change.

It constitutes a daunting brief, and the risk of real dislocations in the service means that it must be accomplished 